\title{
Ligninolytic Ability and Potential Biotechnology Applications of the South American Fungus Pleurotus laciniatocrenatus
}

\author{
M.C.N. SAPARRAT ${ }^{\mathrm{a}}$, F. GUILLÉN ${ }^{b}$ \\ anstituto de Botánica Spegazzini, Facultad de Ciencias Naturales y Museo, Universidad Nacional de La Plata, \\ 1900 La Plata, Argentina \\ e-mail masaparrat@yahoo.com.ar

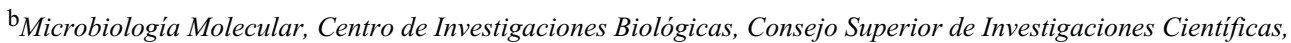 \\ 28040 Madrid, Spain
}

Received 22 June 2004

Revised version 21 December 2004

\begin{abstract}
The extracellular ligninolytic enzyme system of Pleurotus laciniatocrenatus, grown under different culture conditions, was characterized and the ability of this strain to degrade different components of Eucalyptus globulus wood was determined. In shaken liquid cultures grown on a C-limited medium supplemented with yeast extract $(0.1 \%)$ and peptone $(0.5 \%)$, the fungus produced extracellular aryl-alcohol oxidase (Aao), laccase ( $\mathrm{Lac}$ ), manganese-dependent peroxidase (MnP) and manganese-independent peroxidase (MiP) activities, their maximum levels being, respectively, about 600, 50, 1360, and $920 \mathrm{pkat} / \mathrm{mL}$. The supplementation of $1 \mathrm{mmol} / \mathrm{L}$ vanillic acid and $150 \mu \mathrm{mol} / \mathrm{L} \mathrm{CuSO}_{4}$ produced an increase of Lac activity levels up to 4-fold and 68.3-fold, respectively. No significant differences were found in the levels of the other ligninolytic enzyme activities when compared to the basal medium. Solid-state fermentation cultures on E. globulus wood chips revealed Lac and MiP activities. These cultures showed degradative activity on lignin and lipophilic wood extractives.
\end{abstract}

Biodiversity, defined as the variety and richness of life forms on Earth, includes genetic pools, species, ecosystems and the ecological processes of which they are a part (Hawksworth 2001). Even though South American biodiversity is well known, this knowledge is mainly based on the study of vascular plants and vertebrates. At the moment, there is no comprehensive study on the wood-rotting fungi from South America, which play a fundamental role in nutrient cycling and are potential tools for biotechnological applications. However, the available evidence suggests that the fungal diversity in this continent is high (Hawksworth 2001; Ryvarden 1996). Therefore, a contribution to the knowledge of fungal diversity from South America would be important for building a better theoretical background, as well as for applied uses in solving real-world problems. In this sense, several white-rot fungi and their extracellular ligninolytic enzymes are currently being studied (Abdullah and Zafar 1999; Cing et al. 2003; Johannes and Majcherczyk 2000; Kahraman and Yeşilada 2003; Martínez et al. 1994, 1999; Saparrat et al. 2002; Tomšovský and Homolka 2003; Wong and Yu 1999).

The genus Pleurotus is well known for the production of edible mushrooms and includes strongly ligninolytic species. Different Pleurotus species are being extensively studied due to their ability to degrade lignin and other aromatic pollutants causing environmental problems (Cohen et al. 2002; Eichlerová et al. 2003; Kahraman and Yeşilada 2003; Martínez et al. 1994; Novotný et al. 1999; Rodríguez et al. 2004). These fungi have developed a nonspecific oxidative system to degrade aromatic recalcitrant compounds, including extracellular oxidases and peroxidases, low-molar-mass metabolites and activated oxygen species (Sannia et al. 1986, 1991; Bourbonnais and Paice 1989; Guillén et al. 1994, 2000; Martínez et al. 1996; Muñoz et al. 1997; Giardina et al. 2000).

Pleurotus laciniatocrenatus (SPEG.) SPEG. (Agaricales, Basidiomycetes) is a South American fungus, largely found in warm and temperate regions of Argentina, Brazil, Paraguay and Uruguay, which has been relatively little studied compared to other Pleurotus species. P. laciniatocrenatus has shown capability to colonize different lignocellulosic substrates (Salusso and Moraña 1997) and ABTS-oxidizing activity in solid medium (Saparrat et al. 2000). However, no information about the enzyme system of this fungal species has been reported. The aim of our work was to provide knowledge on the enzyme composition of the ligninolytic system of $P$. laciniatocrenatus (CLPS 39 strain), grown under different culture conditions, as well as its ability to degrade different components from Eucalyptus globulus LABILL. wood. This approach 
would contribute to explore autochthonous fungal species for biotechnological processes and increase our knowledge about the enzyme characteristics and ecophysiology of South American fungi.

\section{MATERIALS AND METHODS}

Fungal strain. Pleurotus laciniatocrenatus CLPS 39 (Culture Collection of the La Plata Spegazzini Institute, Argentina) was isolated from the tissue of a fruiting-body collected from the trunk of a Taxodium sp. living tree in an urban forest area (Parque Pereyra woodland; Buenos Aires Province, Argentina). Stock cultures were maintained on slants containing malt extract agar supplemented with $0.4 \%$ yeast extract and Populus nigra $\mathrm{L}$. wood chips at $4{ }^{\circ} \mathrm{C}$.

Liquid cultures. The production of extracellular ligninolytic enzymes was carried out on a basal C-limited medium supplemented with $0.1 \%$ yeast extract and $0.5 \%$ peptone (Saparrat et al. 2002). The effect of $\mathrm{CuSO}_{4} \cdot 5 \mathrm{H}_{2} \mathrm{O}(150 \mu \mathrm{mol} / \mathrm{L})$ and vanillic acid $(1 \mathrm{mmol} / \mathrm{L})$ on the extracellular ligninolytic enzyme system was tested by adding them on the 3rd day of incubation to cultures grown on basal medium. The strain was cultivated in 1-L Erlenmeyer flasks with $200 \mathrm{~mL}$ medium, under shaking $(2.5 \mathrm{~Hz})$ at $25 \pm 1.5^{\circ} \mathrm{C}$; a mycelial suspension was used as inoculum (Saparrat et al. 2002). The cultures were done in three replicates. Aliquots of $5 \mathrm{~mL}$ were taken periodically from each replicate flask. The mycelium was separated from the culture liquid by centrifugation $\left(10000 \mathrm{~g}, 4^{\circ} \mathrm{C}, 30 \mathrm{~min}\right)$. The supernatant of the liquid culture was collected to measure reducing sugars, protein, $\mathrm{pH}$ and enzyme activity.

Solid-state fermentation (SSF). The CLPS 39 strain was cultivated in 100-mL Erlenmeyer flasks containing $2 \mathrm{~g}$ (dry mass) of $E$. globulus wood chips $(1-2 \times 10-20 \mathrm{~mm})$ and $5 \mathrm{~mL}$ water (sterilized at $121{ }^{\circ} \mathrm{C}$ for 2 periods of $30 \mathrm{~min}$ ) that were inoculated with two mycelium plugs (diameter $5 \mathrm{~mm}$ ) from cultures on $2 \%$ malt extract agar. The inoculated flasks were incubated at $28 \pm 1.5^{\circ} \mathrm{C}$ under stationary conditions and constant humidity. Six replicates were done in parallel. Uninoculated sterilized flasks containing wood were incubated under the same conditions as control. After 15 and $30 \mathrm{~d}$, three replicate flasks were analyzed for the presence of ligninolytic enzyme activity (expressed as pkat/g wood). The extraction of enzymes from wood treated with the fungus was carried out by adding $10 \mathrm{~mL}$ of $50 \mathrm{mmol} / \mathrm{L}$ sodium tartrate buffer (pH 5) to SSF cultures and shaking $\left(0.83 \mathrm{~Hz}, 2 \mathrm{~h}, 4{ }^{\circ} \mathrm{C}\right)$; the enzyme extracts were obtained by filtration and dialysis against the same extraction buffer. Simultaneously, the other three cultures were analyzed in order to estimate wood mass loss and the degradation of Klason lignin and acetone extractives of eucalypt wood treated with the fungus.

Analytical methods. Extracellular protein was determined according to Bradford (1976), using BioRad protein assay and bovine serum albumin as standard. Reducing sugars were assayed by the Somogyi and Nelson method (Somogyi 1945), using glucose as standard. Dry mass of wood was determined at $60 \pm 5{ }^{\circ} \mathrm{C}$ in an aerated oven for $12 \mathrm{~h}$. Lipophilic wood-acetone extract compounds were obtained via Soxhlet extraction of sawdust $(<0.4 \mathrm{~mm})$, from control wood and from wood treated with the fungus, with acetone for $6 \mathrm{~h}$ (Martínez et al. 1999). The acetone extracts were evaporated to dryness for mass estimation. Klason lignin content was determined according to TAPPI (1993). The determinations were done in triplicates.

Enzyme assays. Aryl-alcohol oxidase (EC 1.1.3.7; Aao) activity was estimated through veratraldehyde formation from $5 \mathrm{mmol} / \mathrm{L}$ veratryl alcohol (Fluka) in $0.1 \mathrm{~mol} / \mathrm{L}$ phosphate buffer, $\mathrm{pH} 6$ (Guillén et al. 1994). Laccase (EC 1.10.3.2; Lac) activity was measured using $5 \mathrm{mmol} / \mathrm{L}$ 2,6-dimethoxyphenol (Fluka) in $0.1 \mathrm{~mol} / \mathrm{L}$ sodium tartrate buffer, $\mathrm{pH} 3$ (Martínez et al. 1996). Lignin peroxidase (EC 1.11.1.14; LiP) activity was determined by $\mathrm{H}_{2} \mathrm{O}_{2}$-dependent veratraldehyde formation from $2 \mathrm{mmol} / \mathrm{L}$ veratryl alcohol in $0.1 \mathrm{~mol} / \mathrm{L}$ sodium tartrate buffer, $\mathrm{pH} 3$; all reactions were started by the addition of $0.4 \mathrm{mmol} / \mathrm{L} \mathrm{H}_{2} \mathrm{O}_{2}(\mathrm{Sa}-$ parrat et al. 2002). Manganese-dependent peroxidase (EC 1.11.1.13; MnP) activity was estimated by the formation of $\mathrm{Mn}^{3+}$-tartrate complex during the oxidation of $0.1 \mathrm{mmol} / \mathrm{L} \mathrm{Mn}^{2+}$ (as $\left.\mathrm{MnSO}_{4}\right)$ in $0.1 \mathrm{~mol} / \mathrm{L}$ sodium tartrate buffer ( $\mathrm{pH} 5$ ) in the presence of $0.1 \mathrm{mmol} / \mathrm{L} \mathrm{H}_{2} \mathrm{O}_{2}$ (Martínez et al. 1996). Manganese-independent peroxidase (EC 1.11.1.7, MiP) activity was assayed as Lac activity in the presence of $0.1 \mathrm{mmol} / \mathrm{L}$ $\mathrm{H}_{2} \mathrm{O}_{2}$. All the oxidation rates were determined at $25^{\circ} \mathrm{C}$, using a Beckman DU 640 UV-VIS spectrophotometer. The enzyme activity is expressed in pkat (picokatals; 1 pkat is the enzyme activity releasing 1 pmol of oxidized product per s).

Statistical analysis. The effect of vanillic acid and $\mathrm{CuSO}_{4}$ on extracellular ligninolytic enzyme activity levels, compared to cultures grown on basal medium, was analyzed statistically using one-way ANOVA with Tukey's honestly significant difference contrasts. 


\section{RESULTS AND DISCUSSION}

P. laciniatocrenatus grown under shaking in a C-limited medium with $0.1 \%$ yeast extract and $0.5 \%$ peptone was found to be in trophophase until the 6th day of incubation, exhibiting an idiophase under C-limited conditions during the rest of the incubation (Fig. 1). A slight increase in the initial $\mathrm{pH}$ (5.8) was observed during the trophophase, followed by an acidification at the beginning of idiophase and a further increment of $\mathrm{pH}$ to values close to neutrality. Extracellular proteins exhibited a pattern of net consumption during the trophophase, followed by a production peak $(121 \pm 9.6 \mu \mathrm{g} / \mathrm{mL})$ after $9 \mathrm{~d}$. Shaken cultures of P. laciniatocrenatus on C-limited peptone-yeast extract medium revealed different ligninolytic enzyme activities. Peptone has been reported to contain peptides that induce the secretion of peroxidases in Pleurotus species and other basidiomycetes (Kaal et al. 1993; Martínez et al. 1996). Whereas MnP activity with maximum levels $\approx 1360 \mathrm{pkat} / \mathrm{mL}$ was detected during the trophophase, Aao activity, which attained a peak of $600 \mathrm{pkat} / \mathrm{mL}$, was only detected after glucose depletion. However, Lac activity, which revealed low levels (50 pkat $/ \mathrm{mL}$ ), and MiP activity, whose maximum was about 920 pkat $/ \mathrm{mL}$, were detected in relation to both the trophophase and under C-limited conditions. No LiP activity was detected in the supernatant of liquid cultures under our working conditions. In this sense, it is necessary to remark that a $\mathrm{Mn}^{2+}$-oxidizing peroxid-

Fig. 1. Time course of enzyme activities (nkat/mL; Aao, open squares; Lac, circles; $\mathrm{MiP}$, closed squares; MnP, triangles) and reducing sugars ( $\mathrm{mmol} / \mathrm{L}$; closed triangles) in the extracellular fluid of shaken Pleurotus laciniatocrenatus cultures grown in C-limited peptone-yeast extract medium; means of three replicates $\pm \mathrm{SD}$.

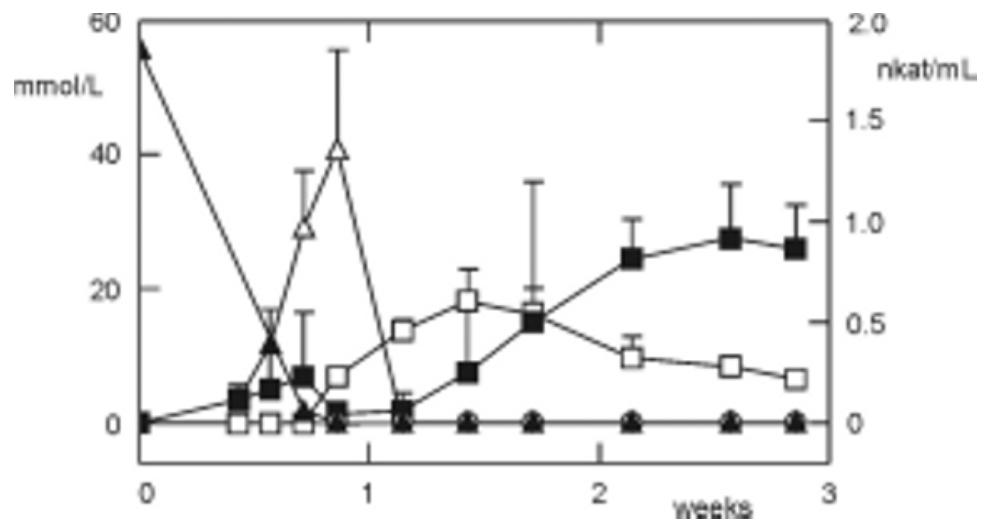

ase, sharing catalytic properties with LiP and MnP, was first reported for P. eryngii (Martínez et al. 1996). This enzyme, called afterwards versatile peroxidase (VP) and reported in other Pleurotus and Bjerkandera species (Camarero et al. 1996; Sarkar et al. 1997; Heinfling et al. 1998; Mester and Field 1998), showed a high activity on $\mathrm{Mn}^{2+}$ but also on phenolic and nonphenolic aromatic compounds without $\mathrm{Mn}^{2+}$. The MnP and MiP activities detected in P. laciniatocrenatus could correspond to the VP enzyme. However, the differences in the production pattern of $\mathrm{MnP}$ and $\mathrm{MiP}$ in this fungus suggest that the MnP activity could be related to the $\mathrm{Mn}^{2+}$-oxidizing enzyme reported for other Pleurotus species, whereas the MiP activity could correspond to a different type of peroxidase in these fungi. Such activity had been reported only in Bjerkandera sp. (de Jong et al. 1992).

The addition of $\mathrm{CuSO}_{4}$ or vanillic acid to the basal medium did not produce significant differences in the patterns and levels of extracellular Aao and $\mathrm{MnP}$ activities, and in the $\mathrm{pH}$, proteins and reducing sugars under our experimental conditions. However, the presence of both compounds affected the Lac and MiP activities (Table I). Lac activity was significantly increased by the addition of vanillic acid to a maximum level of $200 \mathrm{pkat} / \mathrm{mL}$ on the 5th day $(p \leq 0.05)$. This value represents a 4 -fold increase, compared to cultures grown on basal medium. The increase in Lac activity levels by this compound was previously reported for other white-rot basidiomycetes, including Pleurotus species (Hatakka 1994; Muñoz et al. 1997; Farnet et al. 1999). The Lac activity of $P$. laciniatocrenatus was also increased by the addition of $\mathrm{CuSO}_{4}$, showing a peak titer after $14 \mathrm{~d}$ of incubation $(3420 \mathrm{pkat} / \mathrm{mL}, p \leq 0.01)$. In this case, the resulting activity level was 68 times higher than that found in the basal medium. A strong induction of Lac activity by copper had been also described in the basidiomycetes Coriolopsis rigida, Phanerochaete chrysosporium, Pleurotus ostreatus and Trametes versicolor (Collins and Dobson 1997; Dittmer et al. 1997; Palmieri et al. 2000; Saparrat et al. 2002). No significant differences were found in MiP activity levels in the supplemented cultures in relation to control ones, although the presence of $\mathrm{CuSO}_{4}$ revealed the maximum activity earlier than in the basal medium, which was significantly different from the results obtained with vanillic acid $(p \leq 0.05)$. Although no increase of peroxidase activity has been found in P. laciniatocrenatus cultures with the above 
compounds, it has been reported that they are effective inducers of these enzymes in other basidiomycetes (Rogalski et al. 1991; Hatakka 1994; Schlosser et al. 1997; Levin et al. 2002).

Table I. Effect of $150 \mu \mathrm{mol} / \mathrm{L} \mathrm{CuSO}_{4}(\mathrm{Cu})$ and $1 \mathrm{mmol} / \mathrm{L}$ vanillic acid (Va) on the levels of extracellular Lac and MiP activities (pkat $/ \mathrm{mL}$; mean $\pm \mathrm{SD}$ of three replicates) in liquid cultures of $P$. laciniatocrenatus grown on a C-limited peptone-yeast extract medium.

\begin{tabular}{|c|c|c|c|c|c|c|}
\hline \multirow{2}{*}{$\begin{array}{l}\text { Culture time } \\
\text { d }\end{array}$} & \multicolumn{3}{|c|}{ Lac activity } & \multicolumn{3}{|c|}{ MiP activity } \\
\hline & control & $+\mathrm{Cu}$ & $+\mathrm{Va}$ & control & $+\mathrm{Cu}$ & $+\mathrm{Va}$ \\
\hline 4 & $20 \pm 0$ & $50 \pm 30$ & $180 \pm 20$ & $170 \pm 240$ & $290 \pm 230$ & $240 \pm 0$ \\
\hline 5 & $40 \pm 10$ & $160 \pm 60$ & $200 \pm 10$ & $320 \pm 230$ & $820 \pm 220$ & $360 \pm 310$ \\
\hline 6 & $20 \pm 20$ & $670 \pm 220$ & $40 \pm 10$ & $40 \pm 60$ & $360 \pm 40$ & $0 \pm 10$ \\
\hline 8 & $30 \pm 0$ & $1300 \pm 350$ & $30 \pm 10$ & $60 \pm 90$ & $300 \pm 140$ & $10 \pm 10$ \\
\hline 10 & $30 \pm 10$ & $1480 \pm 570$ & $30 \pm 10$ & $250 \pm 360$ & $570 \pm 180$ & $140 \pm 70$ \\
\hline 12 & $40 \pm 10$ & $2910 \pm 470$ & $20 \pm 10$ & $500 \pm 330$ & $460 \pm 230$ & $330 \pm 120$ \\
\hline 15 & $50 \pm 0$ & $3420 \pm 680$ & $30 \pm 10$ & $810 \pm 200$ & $330 \pm 120$ & $1300 \pm 70$ \\
\hline 18 & $50 \pm 10$ & $3120 \pm 100$ & $40 \pm 0$ & $920 \pm 270$ & $260 \pm 110$ & $1250 \pm 70$ \\
\hline 20 & $30 \pm 0$ & $3040 \pm 110$ & $30 \pm 10$ & $870 \pm 210$ & $180 \pm 130$ & $1200 \pm 160$ \\
\hline
\end{tabular}

The existence of different ligninolytic enzymes depends on the fungal species, though it has been reported that differences in the enzyme expression could be a consequence of the culture conditions (Rogalski et al. 1991; Hatakka 1994; Ruiz-Dueñas et al. 1999). The ligninolytic enzymes of P. laciniatocrenatus on eucalypt wood SSF cultures, as well as the degradation of lignin and lipophilic wood extracts, are shown in Table II. This wood was chosen since it is currently used as raw material for paper pulp manufacturing in certain Latin American countries, e.g., Brazil, Argentina and Uruguay. In spite of the inducing effect of lignin and/or lignocellulose on the activity and expression of the ligninolytic enzyme system in different basidiomycetes (Rogalski et al. 1991; Muñoz et al. 1997; Schlosser et al. 1997), only extracellular Lac and MiP activities were found in P. laciniatocrenatus SSF enzyme extracts. Similar results were reported for other Pleurotus species under similar conditions (Rodríguez et al. 2004). In P. laciniatocrenatus SSF cultures the mass loss of eucalypt wood was also determined, as well as the degradation of lignin and acetone wood extractives after 15 and $30 \mathrm{~d}$ of incubation (Table II). The low mass loss of the wood treated with $P$. laciniatocrenatus is a prerequisite for wood pretreatment in paper pulp manufacture (to avoid yield loss in the process). The percentage of lignin and acetone wood extractive degradation was increased about twice after $30 \mathrm{~d}$ compared to those obtained after $15 \mathrm{~d}$. The capacity of different Pleurotus species and other basidiomycetes to degrade lignin has been related to ligninolytic enzyme production (Hatakka 1994; Camarero et al. 1996). It is necessary to emphasize that basidiomycetes have been described as the most adequate fungi for pith biocontrol in eucalypt wood SSF cultures (Martínez et al. 1999) and the use of laccases and peroxidases seems to be also involved in the transformation of wood extractives (Buchert et al. 2001; del Río et al. 2002).

Table II. Eucalyptus globulus wood treatment with Pleurotus laciniatocrenatus

\begin{tabular}{|c|c|c|c|c|c|}
\hline \multirow{2}{*}{$\begin{array}{l}\text { Incubation } \\
\text { time, } d\end{array}$} & \multicolumn{2}{|c|}{ Enzyme activity ${ }^{\mathrm{a}}$, pkat/g wood } & \multirow{2}{*}{$\begin{array}{c}\text { Wood mass loss }{ }^{\mathrm{a}, \mathrm{b}} \\
\%\end{array}$} & \multirow{2}{*}{$\begin{array}{c}\text { Lignin } \\
\text { degradation }^{\text {a,b,c }} \\
\%\end{array}$} & \multirow{2}{*}{$\begin{array}{c}\text { Acetone-extractive } \\
\text { removal }{ }^{\mathrm{a}, \mathrm{b}}, \%\end{array}$} \\
\hline & Lac & MiP & & & \\
\hline 15 & $470 \pm 120$ & $150 \pm 60$ & $1.8 \pm 0.5$ & $1.9 \pm 0.6$ & $11.7 \pm 3.6$ \\
\hline 30 & $480 \pm 160$ & $160 \pm 50$ & $2.4 \pm 1.0$ & $3.6 \pm 1.1$ & $21.6 \pm 4.1$ \\
\hline
\end{tabular}

${ }^{\text {a Means }} \pm \mathrm{SD}$ of three replicates.

${ }^{\mathrm{c}}$ Analyzed by the Klason method.

${ }^{\mathrm{b}}$ Degradation in relation to the content of uninoculated sterilized wood chips (control).

The genus Pleurotus and/or its enzymes are being studied for applications in different industries (edible protein production, applications in paper and pulp production and bioremediation studies). Our work provides preliminary information on the ability of a South American Pleurotus strain to produce enzymes that are currently being tested for biotechnological applications from other wood fungi, and to degrade lignin and extractives from E. globulus wood. Since a thorough knowledge of the biodiversity of a given area 
permits the exploration of potential uses of autochthonous biological resources for the implementation of new environmentally-sound methods and technology, the relevance of studies focusing on our fungal diversity must be emphasized.

The first author is recipient of a scholarship from the National Council of Scientific and Technological Research. This research was supported by grants from the National Council of Scientific and Technological Research and the National University of La Plata, Argentina.

\section{REFERENCES}

ABDULlAH N., ZAFAR S.I.: Lignocellulose biodegradation by white-rot Basidiomycetes: overview. Internat.J.Mushroom Sci. 2, 59-78 (1999).

Bourbonnais R., PAice M.G.: Oxidative enzymes from the lignin-degrading fungus Pleurotus sajor-caju, pp. 472-481 in N.G. Lewis, M.G. Paice (Eds): Plant Cell Wall Polymers: Biogenesis and Biodegradation. ACS Symp. Ser. Vol. 399. American Chemical Society, Washington (DC) 1989.

BRADFORD M.M.: A rapid and sensitive method for the quantitation of microgram quantities of protein utilizing the principle of proteindye binding. Anal.Biochem. 72, 248-254 (1976).

Buchert J., Mustranta A., KontKanen H., Karlsson S., TenKanen M., Holmbom B.: Enzymatic control of wood extractives. Proc. 11th Internat. Symp. Wood Pulp Chemistry 3, 375-378 (2001).

Camarero S., Böckle B., Martínez M.J., Martínez A.T.: Manganese-mediated lignin degradation by Pleurotus pulmonarius. Appl. Environ.Microbiol. 62, 1070-1072 (1996).

Cing S., Asma(Hamamci) D., Apohan E., Yeșilada O.: Decolorization of textile dyeing wastewater by Phanerochaete chrysosporium. Folia Microbiol. 47, 639-642 (2003).

COHEN R., PERSKY L., HADAR Y.: Biotechnological applications and potential of wood-degrading mushrooms of the genus Pleurotus. Appl.Microbiol.Biotechnol. 58, 582-594 (2002).

Collins P.J., DoBSON A.D.W.: Regulation of laccase gene transcription in Trametes versicolor. Appl.Environ.Microbiol. 63, 34443450 (1997).

Dittmer K., Patel N., Dhawale S.W., Dhawale S.S.: Production of multiple laccase isoforms by Phanerochaete chrysosporium grown under nutrient sufficiency. FEMS Microbiol.Lett. 149, 65-70 (1997).

Eichlerová I., Homolka L., Nerud F.: Decolorization of orange G by Pleurotus ostreatus monokaryotic isolates with different laccase activity. Folia Microbiol. 48, 775-779 (2003).

FARnet A.M., TAgger S., LE PetiT J.: Effects of copper and aromatic inducers on the laccases of the white-rot fungus Marasmius quercophilus. Acad.Sci.Paris, Sciences de la vie 322, 499-503 (1999).

Giardina P., Palmieri G., Fontanella B., Rivieccio V., Sannia G.: Manganese peroxidase isoenzymes produced by Pleurotus ostreatus grown on wood sawdust. Arch.Biochem.Biophys. 376, 171-179 (2000).

Guillén F., Martínez A.T., Martínez M.J., Evans C.S.: Hydrogen peroxide-producing system of Pleurotus eryngii involving the extracellular enzyme aryl-alcohol oxidase. Appl.Microbiol.Biotechnol. 41, 465-470 (1994).

Guillén F., Gómez-Toribio V., MuÑoz C., Martínez M.J., MARTínez A.T.: Production of hydroxyl radical by the synergistic action of fungal laccase and aryl-alcohol oxidase. Arch.Biochem.Biophys. 382, 142-147 (2000).

HATAKKA A.: Lignin-modifying enzymes from selected white-rot fungi - production and role in lignin degradation. FEMS Microbiol. Rev. 13, 125-135 (1994).

HAWKSWORTH D.L.: The magnitude of fungal diversity: the 1.5 million species estimate revisited. Mycol.Res. 105, 1422-1432 (2001).

Heinfling A., Ruiz-Dueñas F.J., MARtínez M.J., Bergbauer M., SzEWZYK U., MARTínez A.T.: A study on reducing substrates of manganese-oxidizing peroxidases from Pleurotus eryngii and Bjerkandera adusta. FEBS Lett. 428, 141-146 (1998).

JOHANNES C., MAJCHERCZYK A.: Natural mediators in the oxidation of polycyclic aromatic hydrocarbons by laccase mediator systems. Appl.Environ.Microbiol. 66, 524-528 (2000).

DE JONG E., FIELD J.A., DE BONT J.A.M.: Evidence for a new extracellular peroxidase: manganese inhibited peroxidase from the whiterot fungus Bjerkandera sp. BOS55. FEBS Lett. 299, 107-110 (1992).

KAAL E.E.J., DE JONG E., FIELD J.A.: Stimulation of ligninolytic peroxidase activity by nitrogen nutrients in the white-rot fungus Bjerkandera sp. strain BOS55. Appl.Environ.Microbiol. 59, 4031-4036 (1993).

KAHRAMAN S., YeŞILADA O.: Decolorization and bioremediation of molasses wastewater by white-rot fungi in a semi-solid-state condition. Folia Microbiol. 48, 525-528 (2003).

LeVIN L., Forchiassin F., Ramos A.M.: Copper induction of lignin-modifying enzymes in the white-rot fungus Trametes trogii. Mycologia 94, 377-383 (2002).

martínez A.T., Camarero S., Guillén F., Gutiérrez A., Muñoz C., Varela E., Martínez M.J., Barrasa J.M., Ruel K., PELAYO J.: Progress in biopulping of non-woody materials: chemical, enzymatic and ultrastructural aspects of wheat straw delignification with ligninolytic fungi from the genus Pleurotus. FEMS Microbiol.Rev. 13, 265-274 (1994).

MARtínez M.J., Ruiz-DueÑAs F.J., GuillÉN F., MARTínEZ A.T.: Purification and catalytic properties of two manganese-peroxidase isoenzymes from Pleurotus eryngii. Eur.J.Biochem. 237, 424-432 (1996).

MARtíneZ M.J., BARRASA J.M., GuTIÉRREZ A., DEL Río J.C., MARTínEZ A.T.: Fungal screening for biological removal of extractives from Eucalyptus globulus wood. Can.J.Bot. 77, 1513-1522 (1999).

MESTER T., FIELD J.A.: Characterization of a novel manganese peroxidase-lignin peroxidase hybrid isozyme produced by Bjerkandera species strain BOS55 in the absence of manganese. J.Biol.Chem. 273, 15412-15417 (1998).

MuÑoz C., Guillén F., MARTínez A.T., MARTínez M.J.: Induction and characterization of laccase in the ligninolytic fungus Pleurotus eryngii. Curr.Microbiol. 34, 1-5 (1997).

Novotný Č., ERBAnovÁ P., ŠAŠEK V., KubÁtovÁ A., CAJTHAMl T., LANG E., Krahl J., ZadRAZIL F.: Extracellular oxidative enzyme production and PAH removal in soil by exploratory mycelium of white-rot fungi. Biodegradation 10, 159-168 (1999).

PAlmieri G., Giardina P., Bianco C., Fontanella B., SANNia G.: Copper induction of laccase isoenzymes in the ligninolytic fungus Pleurotus ostreatus. Appl.Environ.Microbiol. 66, 920-924 (2000). 
DEL Río J.C., GUTIÉRREZ A., MARTínEZ M.J., MARTíNEZ A.T.: Identification of a novel series of alkylitaconic acids in wood cultures of Ceriporiopsis subvermispora by gas chromatography/mass spectrometry. Rapid Commun.Mass Spectrom. 16, 62-68 (2002).

Rodríguez E., Nuero O., Guillén F., Martínez A.T., Martínez M.J.: Degradation of phenolic and non-phenolic aromatic pollutants by four Pleurotus species: the role of laccase and versatile peroxidase. Soil Biol.Biochem. 36, 909-916 (2004).

Rogalski J., Lundell T., LeONOwiCZ A., HAtAKKA A.: Production of laccase, lignin peroxidase and manganese-dependent peroxidase by various strains of Trametes versicolor depending on culture conditions. Acta Microbiol.Polon. 40, 221-234 (1991).

Ruiz-Dueñas F.J., Guillén F., CAMArero S., PÉREZ-BoAda M., Martínez M.J., Martínez A.T.: Regulation of peroxidase transcript levels in liquid cultures of the ligninolytic fungus Pleurotus eryngii. Appl.Environ.Microbiol. 65, 4458-4463 (1999).

RYVARDEN L.: Biodiversity in polypore fungi. A comparison between tropical Africa and America. Rev.Biol.Trop. 44, 125-129 (1996).

Salusso M., Moraña L.B.: Cultivo de Pleurotus laciniatocrenatus en Argentina. Rev.Iberoam.Micol. 14, 129-130 (1997).

SANNIA G., GiARDinA P., LunA M., Rossi M., BuONOCORE F.: Laccase from Pleurotus ostreatus. Biotechnol.Lett. 8, 797-800 (1986).

SAnNia G., Limongi P., CocCA E., BuOnOCORE F., NitTi G., Giardina P.: Purification and characterization of a veratryl-alcohol oxidase enzyme from the lignin degrading basidiomycete Pleurotus ostreatus. Biochim.Biophys.Acta 1073, 114-119 (1991).

SAPARrat M.C.N., BucsinszKy A.M.M., TourniER H.A., CABEllo M.N., ArAmBarRi A.M.: Extracellular ABTS-oxidizing activity of autochthonous fungal strains from Argentina in solid medium. Rev.Iberoam.Micol. 17, 64-68 (2000).

SAPARRAT M.C.N., Guillén F., ARAMBARRi A.M., MARTínez A.T., MARTíNEZ M.J.: Induction, isolation, and characterization of two laccases from the white-rot basidiomycete Coriolopsis rigida. Appl.Environ.Microbiol. 68, 1534-1540 (2002).

SARKAR S., MARTíNEZ A.T., MARTÍNEZ M.J.: Biochemical and molecular characterization of a manganese peroxidase isoenzyme from Pleurotus ostreatus. Biochim.Biophys.Acta 1339, 23-30 (1997).

SCHLOSSER D., GREY R., FRITSCHE W.: Patterns of ligninolytic enzymes in Trametes versicolor: distribution of extra- and intracellular enzyme activities during cultivation on glucose, wheat straw and beech wood. Appl.Microbiol.Biotechnol. 47, 412-418 (1997).

SOMOGYI M.: A new reagent for determination of sugars. J.Biol.Chem. 160, 61-73 (1945).

TAPPI: Test Methods 1992-1993. Technical Association of the Pulp and Paper Industry, Atlanta (USA) 1993.

TOMŠOVSKÝ M., HOMOLKA L.: Laccase and other ligninolytic enzyme activities of selected strains of Trametes spp. from different localities and substrates. Folia Microbiol. 48, 413-416 (2003).

WONG Y., YU J.: Laccase-catalyzed decolorization of synthetic dyes. Water Res. 33, 3512-3520 (1999). 